PACS: 06.2; 07; 08.

УДК 621.592;537.311,322.

\title{
ACTIVE ULTRASOUND EFFECTS AND THEIR FUTURE USAGE IN SENSOR ELECTRONICS
}

\author{
Ja. M. Olikh, *) O. Ya. Olikh \\ Lashkarov's Institute of Semiconductor Physics NAS Ukraine, \\ Pr. Nauky 41, Kyiv, 03028, Ph: (38044) 2656256, Fax: (38044) 2658342, e-mail: jaroluk3@ukr.net; \\ *)Kiev Taras Shevchenko National University, Physics Faculty, pr.Glushkova 6, 03127, Kyiv, Ukraine, \\ Ph: (38044) 2660510, e-mail: olikh@mail.univ.kiev.ua
}

\section{Summary \\ ACTIVE ULTRASOUND EFFECTS AND THEIR FUTURE USAGE IN SENSOR ELECTRONICS}

\author{
Olikh Ja. M., Olikh O.Ya.
}

In given paper various phenomena of ultrasound influence on physical characteristics of dislocation crystals of $\mathrm{A}_{2} \mathrm{~B}_{6}$ type $\left(\mathrm{CdS}, \mathrm{ZnS}, \mathrm{Cd}_{\mathrm{x}} \mathrm{Hg}_{1-\mathrm{x}} \mathrm{Te}\right)$ and of dislocation-free crystals (Ge, $\mathrm{Si}$ ) are systematized; results for light emitting structures (GaAs, GaAlAs, GaP) are given; possibilities of the active ultrasound use in microelectronics device technology are analyzed.

Separately dynamic effects (in-situ) are considered. Possible mechanisms of sound induced effects and their applications are discussed. New technological techniques such as ultrasound processing, thermoacoustic efect annealing, ultrasound induced doping and so on find an industrial application. A considered aspect of physical and technological effects of ultrasound in semiconductors is proposed for further usage in Sensor electronics:

Key words: semiconductors, ultrasound, active ultrasound, crystal defects, sensor electronics.

\section{Аннотация \\ ЭФФЕКТЫ АКТИВНОГО УЛЬТРАЗВУКА И ПЕРСПЕКТИВА ИХ ПРИМЕНЕНИЯ В СЕНСОРНОЙ ЭЛЕКТРОНИКЕ}

\author{
Я. М. Олих, О. Я. Олих
}

В работе систематизированы разнообразные явления и эффекты ультразвукового воздействия на физические характеристики дислокационных кристаллов, типа $\mathrm{A}_{2} \mathrm{~B}_{6}(\mathrm{CdS}$, $\left.\mathrm{ZnS}, \mathrm{Cd}_{\mathrm{x}} \mathrm{Hg}_{1-\mathrm{x}} \mathrm{Te}\right)$, и бездислокационных — Ge, $\mathrm{Si}$; приводятся результаты для полупроводниковых светоизлучающих структур (GaAs, GaAlAs, GaP); проанализированы возможности использования активного ультразвука (УЗ) в технологии микроэлектронных приборов (термоакустический отжиг дефектов, акустостимулированое легирование методом имплантации ионов примесей). Отдельно рассматриваются динамические эффекты (in-situ), которые проявляются лишь во время воздействия УЗ. Обсуждаются возможные механизмы таких акустостимулированных эффектов и их применение. Рассмотрен- 
ный спектр физических и технологических эффектов УЗ в полупроводниках предложен для последующего их использования в Сенсорной электронике.

Ключевые слова: полупроводники, ультразвук, активный ультразвук, кристаллические дефекты, сенсорная электроника.

\title{
Анотація \\ ЕФЕКТИ АКТИВНОГО УЛЬТРАЗВУКУ ТА ПЕРСПЕКТИВА ЇХ ВИКОРИСТАННЯ В СЕНСОРНІЙ ЕЛЕКТРОНІЦІ
}

\author{
Я. М. Оліх, О. Я. Оліх
}

В роботі систематизовано різноманітні явища та ефекти ультразвукової дії на фізичні, характеристики дислокаційних кристалів типу $\mathrm{A}_{2} \mathrm{~B}_{6}\left(\mathrm{CdS}, \mathrm{ZnS}, \mathrm{Cd}_{\mathrm{x}} \mathrm{Hg}_{1-\mathrm{x}}\right.$ Те) та бездислокаційних (Ge, $\mathrm{Si})$; наводяться результати для напівпровідникових світловипромінюючих структур (GaAs, GaAlAs, GaP); проаналізовано можливості використання активного ультразвуку (УЗ) в технології мікроелектронних приладів (термоакустичний відпал дефектів, акустостимульоване легування методом імплантації іонів домішок). Розглядаються динамічні ефекти (in-situ), які проявляються лише під час дії УЗ. Обговорюються можливі механізми таких акустостимульованих ефектів та їх застосування. Розглянутий спектр фізичних та технологічних ефектів УЗ в напівпровідниках запропоновано для наступного їх використання в сенсорній електроніці.

Ключові слова: напівпровідники, ультразвук, активний ультразвук, кристалічні дефекти, сенсорна електроніка.

\section{Introduction}

In order to study crystal elastic properties and ultrasonic interaction with solids last twenty years together with traditional acoustic methods in solid state physics ultrasonic of Megahertz wave range is used. This new approach makes it possible to control characteristics of semiconductor materials and devices. Mechanism of such process is determined by interaction of acoustic wave (AW) with system of crystal structural defects. Contrary to acoustic-electronic effects when AW interacts directly with the electric field of charge carriers in solids [1-2], acoustic-stimulated phenomena are connected with induced changes in the system of electrical- and optical-active crystal defects. Linear and flat defects of dislocation and sublets types act as the mediators in AW interaction with charge carriers in dislocation crystals; and so called metastable defects which prove themselves as the acoustic-electrical centers - act in dislocation less crystal. This trend of physic acoustoelectronics, which in fact is acoustoelectronics of crystal defects, is called active sound [3,4].

Ultrasound (US) vibrations stimulate transition of system defects to the most equilibrium stable state. This state depends not only upon crystal structure but also on different external factors: temperature, light, electromagnetic field, deformation and so on. Such sensitivity of semiconductors, which might be amplify greatly by external AW action defines the new trend of sensor electronics by usage of dynamic US defects.

The below given short survey of main experimental results of study of ultrasound effects (frequency range of 0.1-100 Megahertz) is caused by practical interest for active sound usage in physics and technology of semiconductors as well as its future wide possibility in other branches. It is 
worthy to mention that these methods do not apply directly to traditional ultrasound usage (of kilohertz range) in such procedures as US intensification of chemical and technological processes, US detail treatment, US dispersion, US cleaning of surfaces solids (including semiconductor materials) and many others [2].

\section{Main mechanisms of acoustic wave interaction with crystals}

Distributing through real crystal, AW interacts with its lattice, conductive electrons and lattice defects and thus causes property changes and appearing of some acoustic-stimulated phenomena in solids. Let us consider possible mechanisms of AW interaction with crystals [1,2,4-6].

\section{1) AW interaction with crystal lattice vibration.}

Thermal vibrations of crystal lattice one can consider as the total longitudinal and transverse elastic waves, thermal phonons. AW interaction with lattice vibrations might be consider as phonon-phonon interaction. There are two main approaches. The first one developed in L. Landau and Yu. Rammer works (1937), is based on the conception about three-phonons interaction. According to this conception sound and thermal phonons are consider to be quasi-particles, due to their interaction the third phonon is born. Such approach is valid at low temperatures and high US frequencies. A. Akhiezer in 1938 studied the other border case -relatively low frequencies and high temperatures. According to this concept AW is consider as an external action, which causes perturbation of the thermal phonon system and breaks equilibrium thermodynamic distribution.

\section{2) AW interaction with conductive electrons.}

The mechanism mentioned is caused by the fact that atom displacements in crystal lattice due to AW passing through material cause inter-crystal field changes, which have influence on conductive electron movement. In turn the reverse effect occurs: change of conductive electron state influences on inter-crystal fields, thus causing lattice deformation, which can lead to changes of propagating velocity and AW absorption coefficient. Under acoustic-electron (AE) interaction pulse and energy exchange between electron and phonon sub-systems occurs. The interaction causes phenomenon of electronic US absorption, US amplifying, different AE effects. Depending on crystal type such mechanisms of AE interactions are known:

i) Potential-deforming. It is caused by change of band structure of solids under crystal lattice deformation. Due to this change the semiconductor forbidden bandwidth, effective mass and lifetime of charge carriers occur. The mechanism becomes apparent at high frequencies $\left(>10^{9} \mathrm{~Hz}\right)$ in nonpolar semiconductors (Ge, $\mathrm{Si}$ ) and semi-metal.

ii) Piezoelectric. One can observe it in crystal without symmetry center that is piezo-semiconductors, deformation in which is accompanied by electrical field appearing, and vice versa, electrical field produces deformation. Such interaction type is present in crystal of $\mathrm{A}_{2} \mathrm{~B}_{6}$ group $(\mathrm{CdS}, \mathrm{CdSe}, \mathrm{ZnS}$, $\mathrm{ZnO})$ and $\mathrm{A}_{3} \mathrm{~B}_{5}(\mathrm{GaAs}, \mathrm{InSb}, \mathrm{GaSb})$; depending upon sample conductivity it is preferable for 1.0 $1000 \mathrm{MHz}$ frequencies.

iii) Ionic interaction. This type occurs in solids whose atoms are ionized or there is a great amount of ionizing impurities. AW displaces ions from equilibrium sites and in consequence of this, intercrystal field modulates charge carrier movement.

iv) Mechanism, connected with heterogeneous deformation of nonpiezoelectric crystal. Due to AW passing the crystal lattice symmetry is disturbed and polarization appears, which is proportional to the deformation gradient. This mechanism is near to potential-deforming one.

When interpreting AW interacts with electrons, one can also evolve two regions, as in the case of 
phonon-phonon interaction,: classic and quantum (corresponding to high frequency range and large free pass length of electrons).

\section{3) AW interaction with crystal structure defects.}

There are specific mechanisms of AW interaction with crystal structure defects for different materials. For example, in some cases thermal phonons can mediate between point defects and AW. Due to various nonlinear processes of phonon-phonon interaction AW energy causes perturbation of thermal phonon distribution [5].

Acoustic-defect interaction in dislocation crystal is studied in detail the mostly; theoretically and experimentally as well. AW interaction with dislocation system is consider by Keller and in series is developed by Granato and Lucke in the frame of string model of dislocation [8]. Dislocation grid sites are the places of the "string" fixing (heavy locks) and point defects are weak locks. Under US strain action the dislocation commits stimulated vibrations, which causes from one side additional US absorption and, from other side - stimulate the spatial point defect displacement. So, linear defects act as mediators in transferring energy from AW to various point defects. Mobile dislocations in the AW field are followed by strong electric and deformation fields [2,5]; an existence of such fields may in some cases lead to generation and ionization of point defects [9], their movement and redistribution in the crystal. Generation of point defects occurs at least by three ways: by defect dipole annihilation, by steps' crawling over on dislocations and by crossing of dislocations [10]. If first case is the most effective for external stress of constant sigh, for AW it is the easiest to provide reproduction of generation process by the second one $[11,12]$. According to this model one can consider the step on screw dislocation as a specific kind of fix places. Under curtain conditions the step can move with "own" dislocation. This movement is not free; the step displacement between initial and end positions is always supported by the creation of vacancy or interstitial atom, depending on the step movement direction.

For low-dislocation material the theory of acoustic-defect interaction is limited to analysis of only acoustic effects, connected with perturbation of equilibrium function of the thermal phonons' distribution for the low sound intensity case [5,13]. At the same time the state of electrically- and opticallyactive defects or its changes under such interaction is not theoretically study.

\section{Physical processes, connected with ultrasonic influence on crystal defect structure}

AW propagation (even for low intensity) through crystal evokes local sign-changing deformation, appearing of electrical fields in piezoelectrics, local heating, causes dislocation' interaction and multiplication, redistribution of point defects and their space complexes. All these effects of AW interaction with crystal become apparent in wave parameter changes as well as in inter-crystal processes caused by US action. Let us consider some "non-classical" phenomena, caused by US influence on crystal defect structure.

Acoustoluminescence $(A L)$. This phenomenon is connected with appearing of luminescence due the AW passing through crystal. AL was observed for the first time in piezo-electric CdS plates [14]. This effect has threshold that is AW becomes excited, when it reaches certain intensity. This threshold is equal $1 \div 10 \mathrm{Wt} / \mathrm{cm}^{2}$ for $\mathrm{A}_{2} \mathrm{~B}_{6}$ crystal for $\mathrm{MHz}$ band [15]. Experiments testify that observed $\mathrm{AL}$ spectra quite enough reconstruct optical spectra of point defects in appropriate compounds. It makes it to conclude about initial-defect character of AL origination. Due to the dislocation oscillation movement in US field with above-threshold intensity the charge defects appear in crystal. Electronic processes in system of appearing defects are the source of luminescence. Except direct acoustic-stimulated luminescence, US defect generation causes changes in character of crystal luminescence, connected 
with other mechanisms. Especially, influence of acoustic loading on electro luminescence of phosphide gallium crystal was observed [16-18].

Acoustic-photoconductivity (APH).

There is phenomenon of crystal conductivity change and appearing of new bands and lines in photoconductivity spectrum. APH was observed in $\mathrm{ZnS}$, Si, GaAs, KCl, HgCdTe [19-20]. The effect has threshold, caused by generation of defects or their ionization and adequate increase of free charge carriers. Photoconductivity spectrum changes are caused by shallow level activation due to US recharging of defects in crystal [15].

Acoustic-chemical reactions (ACR).

Chemical reactions that occur in crystal due to external action (temperature, pressure, light, electrical field) there are the processes of electrical charge exchange among atoms, rebuilding or displacement of atoms, ions and also destroying of old defect complexes and creation of new ones. In the article [21] while studying AW before-threshold intensity on photoconductive and photoluminescent spectra of exciton-impurity complexes it was stated about rebuilding of system of point defects in $\mathrm{CdS}$ crystal. Oscillation of dislocation segments might be the physical cause of this. One can consider US ionization of local centers as concerning to ACR [9]. Authors of the article [22] have stated that due to AW the spatial transfers of defects occur, which belong to complex defects. This, in tern, leads to change of inter-center action and complex destroy. The authors show the analogy between ACR and photochemical reactions, but stress that in opposition to the last, ACR occurs even at low ( 77K) temperature. This difference testifies that US influence is not limited by only recharging of complex components. It is shown in [23-24], that ACR may homogenize metal ( $\mathrm{Pt}, \mathrm{Cr}, \mathrm{W}$ )-semiconductor $(\mathrm{GaAs})$ structures. Under AW action vacancy and impurity stimulated diffusion occurs. Vacancy flow, while absorbing (or generating) by dislocations, causes crawling and ordering of vacancies.

US modeling of radiation defects and US defect annealing.

In the article [26] authors has observed interesting analogies of changes of photoconductive spectra of Si crystals, irradiated and treated by US. It enable to conclude about possibility of radiation defect modeling by using above threshold US amplitude - US defect generation.

Inverse US annealing of radiation defects is given in [27].

When alkaline-galoid crystals were treated by US then residual decrease of defect concentration was observed. US intensity was a bit greater than threshold value necessary for AL stimulation. In articles $[28,29]$ the results are given concerning the annealing of InP crystals, irradiated by fast electrons and neutron-doped Ge samples, under US loading at the same time. There is so called thermoacoustic annealing. The decrease of temperature of complete annealing was observed (for about 50K). One can explain these effects as the acoustic-stimulated decrease of activation energy of radiation defects and acceleration of their migration to sinks during US loading.

US modification of charge carriers parameters. In order to improve photoelectric parameters of $\mathrm{HgCdTe}$ crystals important results of US treating study were received in papers [30-33]. US treatment with the before threshold intensity leads to the decrease of own acceptor concentration, increase of minority carrier lifetime and decrease of thermal noise. Proposed resonance mechanism of analogous changes is connected with US intensification of break down processes intensification of excess defects, gettering on low-angle limits of subblocks, mercury atoms, in first term, their diffusion into crystal volume and healing of vacancy defects by them. US treading of over threshold intensity cause inverse effects - due to the movement and multiplication of dislocation generation of additional defects of vacancy type occurs. Under such conditions even Hall coefficient inversion can occur [30]. Such residual US changes of electrical and photoelectrical characteristics were observed for CdTe and $\mathrm{ZnCdTe}$ crystals too [34-35]. It was stated correlation between US action character and defect structure of samples. At low dislocation density $\left(\sigma_{d}<10^{5} \mathrm{~cm}^{-2}\right)$ their multiplication with further 
sink of mobile acceptors on dislocations occurs. When $\sigma_{\mathrm{d}}>10^{6} \mathrm{~cm}^{-2}$, the process of acceptor release from dislocation dominates. As it was state (due to acoustic Hall measurements under dynamic US loading) in the region of impurity conductivity of $\mathrm{HgCdTe}$ crystals owing to inter-crystal potential smoothing the increase of charge carrier mobility occurs while in the region of intrinsic conductivity the mobility decreases, owing to the increase of intensity of dispersion on optical phonons [36-37].

US influence on galvanomagnetic effects was observed, too, in dislocation-free $\left(\sigma_{\mathrm{d}}<10^{2} \mathrm{~cm}^{-2}\right) \mathrm{p}-\mathrm{Ge}$ samples. US loading causes the magneto-field characteristics shift, concentration and mobility decrease, and, accordingly, resistivity increase. It was shown that the effect is stronger in weak magnetic field, under temperature decrease and for samples with greater impurity concentration [38].

US influence on the diffusion length of minority charge carriers $\mathrm{L}_{\mathrm{D}}$ was studied in polycrystalline silicon. US treatment leads to $\mathrm{L}_{\mathrm{D}}$ increase in the regions with low initial value of $\mathrm{L}_{\mathrm{D}}<25 \mu \mathrm{m}[39-40]$. The authors connect this process with acoustic-stimulated dissociation of Fe-B pairs. Under acoustic oscillation action the reorientation of complexes occurs and as a result iron atom passed from one interstitial position to another one, which is equivalent. The complex decay occurs when Fe is situated between these equivalent positions owing to the essential decrease of Coulomb bond energy in this position. Increase or decrease of $\mathrm{L}_{\mathrm{D}}$ depends on further iron ion behavior, whether it forms active recombination centers or not. US $\mathrm{L}_{\mathrm{D}}$ increase was observed in monocrystal silicon, too [41]. In this case $L_{D}$ change was inverse by character, that is, after stoppage of US loading the diffusion length value gradually returns (by some dozens of minutes) to initial meaning. In order to explain experimental results the model of acoustic-stimulated reorientation of bistable recombination center was proposed, and this center consist from doping impurity and interstitial metal atom.

Electron emission amplification. Such effect of amplification of electron emission from donor impurities (Se, Te) under US loading of silicon [42] is the next example of US interaction with point defects. The authors consider the phenomenon from the potential-deformation mechanism point of view, which is connected with nonlinear effects and changing stresses, hat cause an impurity atom displacement from an equilibrium position. In the papers $[7,43]$ it was informed about an effective influence of US loading on exciton system in CdS and ZnS crystals.

Rebuilding of defect structure and smoothing of local heterogeneity of $\mathrm{Si}_{-} \mathrm{SiO}_{2}$ interface are given in [44]. Phenomenon of electron center EL5, EL6, EL18 rebuilding and EL2 center transition from metastable state to stable ones owing to US displacement of intrinsic point defects (which are complex parts) was observed in GaAs [45-47].

\section{Practical perspective of US treatment utilization}

Semiconductor technology development rises a question of higher and higher material quality. There are two main ways for obtaining devices of high quality and reliability. The first one is to use highly pure initial materials and then to treat them under strict control of process purity. Another way consists in usage of materials with medium impurity level and further gettering of undesirable defects. Technically the last process consists of successive stages: release of bond impurities (for example, $\mathrm{Cu}$, $\mathrm{Fe}, \mathrm{Cr}$ atoms in $\mathrm{Si}$ ), which are activated in operating device region during preparing of plate or whole device; 2) free impurity movement into direction of getter centers, which are situated outside operation regions; 3) capture of impurity atoms by crystallographic defects or other getters. As one can see from the previous section, in some cases AW effectively influences for all three stages. Thus US treatment may be use to improve parameters of materials with the medium impurity level.

So, it might be considered as a fact that US treatment improves defect structure and, consequently, electric-physical characteristics of silicon and its devices [41,44]. Except mentioned earlier US effects, acousto-stimulated doping impurity diffusion deep into semiconductor [48], certain defect out- 
let on the surface [49], smoothing of local heterogeneities of $\mathrm{Si}_{-} \mathrm{SiO}_{2}$ interface [44], acoustic annealing of unstable radiation defects in MOS-structures [50] were also observed.

Especial interest is devoted to the problem of US interaction with nonequilibrium system of radiation defects, in-situ impurity ion implantation [51]. Implantation of impurity ions into semiconductor crystal leads to radiation defect accumulation. During forming of shallow $\mathrm{p}-\mathrm{n}$ transitions in integrated circuits by ion implantation method an ion channeling occurs, and this causes an essential widening of impurity deposition profile. Using in-situ US treatment makes it possible to decrease critical amorphous dose and to obtain continuous amorphous layer for much lesser concentration of introduce impurity. One can use the effect for the decrease of the channel efficiency of implant electrically active impurities in fabrication of shallow $p$-n junction and also for optimization of processes of solidphase implantation layer recrystalization during defect annealing after implantation.

Acoustic-stimulated diffusion. US influence on crystal point defects was studied for the first time in papers [52-54]. Thus, effect of the US decrease of diffusion activation energy and accordingly the increase of diffusion of $\mathrm{Li}$ [52] and $\mathrm{Cr}$ [53] ions were observed in pollycrystalline silicon. In monocrystal silicon an alkaloid metal K and Na migration stimulated by US from volume to surface was shown in [39]. There are some reports about US induced doping impurity diffusion into depth of Si and GaAs [40]. In MOS-structures, irradiated by $\gamma$-rays, diffusion of unstable radiation defects under US elastic strain was observed [41]. According to the theoretical model, given in the article [55], US diffusion of impurity atom is possible because of its interaction with nonequilibrium phonon, stimulated by US, there is an increase of population of impurity quantum oscillation levels, situated a bit higher than energy minimum. As a result, probability of atom migration onto other levels increases. US healing of vacancy type defects in infrared $\mathrm{CdHgTe}$ detectors leads to the decrease of thermal 1/f noise level of this devices in 10-100 times [56].

Obvious case of effective US treatment influence on acceleration of hydrogenation (atomic hydrogen saturation) of polycrystalline silicon thick films is given in [57,58]. It turned out, that sample treatment at $300^{\circ} \mathrm{C}$ leads to the essential diffusion acceleration and increase of spatial material homogeneity. It is assumed, that acoustic-stimulated hydrogenation mechanism is connected with absorption of US energy by grain boundaries, dislocations and other extensive defects. This, in tern, is supported by stimulated release of hydrogen atoms from capture centers. Acoustic stimulation of the process leads to the transistor parameter improvement. An impotent sample of usage of acoustic influence there is a dynamic US loading of the devices during their operation. These researches are not developed on full scale despite of the fact that its are prospering for design of new class of dynamic acoustic-electrical devices, in which sound might be a convenient instrument of influence on operating device characteristics.

The results, obtained in $[4,25,50-56]$ which applied to US influence on parameters of semiconductor devices, are summarize in Table.

\section{Results}

A considered aspect of physical and technological effects of active ultrasound in semiconductors is proposed for further usage in Sensor electronics:

- Improving of semiconductor and other components of initial materials;

- Increase of operating characteristics stability and durability of sensors due to active ultrasound usage at the process of their manufacturing;

- Widening of functional possibilities of traditional sensors (sensitivity and dynamic ranges, for example) and design of principal new devices by US usage during operation;

- Restoring of sensor operating parameters, degraded after long exploitation or under aggressive environment. 
So, this new technological approach - active ultrasound, - has become a powerful tool of the engineering to improve performance and reliability of sensor semiconductor devices.

\section{Acknowledgment}

This work was partly supported by STCU, project \#2367.

Table.

Improvement of semiconductor device parameters after US treatments

\begin{tabular}{|c|c|c|c|}
\hline Type of device & Material & Improved parameter & Type of US change \\
\hline \hline $\begin{array}{c}\text { Thin-film } \\
\text { transistor }\end{array}$ & $\begin{array}{c}\text { Poly-Si } \\
\text { film }\end{array}$ & $\begin{array}{c}\text { Leakage current, } \\
\text { threshold voltage }\end{array}$ & $\begin{array}{c}\text { Decrease, in } 10 \text { times } \\
\text { decrease for 0,5 V }\end{array}$ \\
\hline Tunnel diode & $\mathrm{GaAs}$ & Current noise & Decrease, in 4 times \\
\hline Photodetector & $\mathrm{CdSe}$ & Dark current & Decrease, in 100 times \\
\hline Integral circuit & $\mathrm{Si}$ & Current noise & Decrease, in 2 times \\
\hline Shotky diod & $\mathrm{GaAs}$ & Back current & Decrease by two orders \\
\hline Light diode & $\mathrm{In}(\mathrm{Al}) \mathrm{GaAs}$ & Intensity & Increase for $90 \%$ \\
\hline Infrared detector & $\mathrm{CdHgTe}$ & 1/f noise level & Decrease, in 100 times \\
\hline
\end{tabular}

\section{References}

1. Труэлл Р., Эльбаум Ч., Чик Б. Ультразвуковые методы в физике твердого тела: Пер. с англ. - М.: Мир, 1977. — 308 с.

2. Ультразвук. Маленькая энциклопедия / Под. ред. И.П. Голямина. - М.: Сов. энциклопедия, 1979. — 400 с.

3. Олих Я.М. Активный звук в физике полупроводн. кристаллов СdHgTe. Тезисы докл. Х11 Всес. конф. по физике полупр. Киев, 1990. Ч.2, стр.87.

4. Островський I.В., Коротченков О.О. Фізична акустооптика: Навчальний посібник. К.: ВЦ “Київський університет”, 2000. - 347 с.

5. Красильников В.А., Крылов В.В. Введение в физическую акустику. - М.: Наука, 1984. $-400 \mathrm{c}$.

6. Гуляев Ю.В., Козорезов А.Г. К теории решеточного поглощения звука в “грязных" кристаллах. ЖЭТФ, -1982, Т.82, В.5, с.1551-1561.

7. Ostrovskii I.V., Korotchenkov O.A., Goto T., Grimmeiss H.G. Sonoluminescense and acoustically driven optical phenomena in solid and solid-gas-interfaces // Phys. Reports. — 1999. — Vol. 311, N1. - P.1-46.

8. Granato A., Lucke K. Theory of mechanical damping due to dislocations // Journ. Appl. Phys. 1956. - Vol.2 7, N6 - p. 583-593.

9. Горелов Б.М., Коротченков О.А., Островский И.В., Шейкман М.К. Ионизация ультразвуком глубоких центров в сульфиде цинка // Письма в ЖТФ. - 1985. — Т. 11, №21 - С. 1315-1320.

10. Фридель Ж. Дислокации: Пер. с англ. - М.: Мир, 1967. — 643 с.

11. Халак Ю.М. До теорії акустолюмінесценції іонних кристалів: Дис... канд. фіз. — мат. наук: 01.04.02. — K., 1997. — 127 c.

12. Loktev V.M., Khalack J. On the nature of ionic crystals' sonoluminescence excitation threshold: point-defect generation // J. Lumin. — 1998. — Vol. 76-77. — P. 560-563. 
13. М.Б.Гитис, И.А.Чайковский. Распространение звука в легированных полупроводниках. Кишинев: Штиинца, 1986. - С.226.

14. Островский И.В., Рожко А.Х., Лысенко В.Н. Ультразвуковая люминисценция монокристалов CdS // Письма в ЖТФ. - 1979. - Т. 5, №15. - С. 910-913.

15. Островский И.В. Акустолюминисценция и дефекты кристаллов. - К.: Вища школа, 1993. - $223 \mathrm{c}$.

16. Здебский А.П., Корчная В.Л., Корчинская Т.В., Шейкман М.К. Стимулированное ультразвуком изменение электрических и люминесцентных характеристик InGaAs:Si светодиодов // Письма в ЖТФ. - 1986. - Т. 12, №2. - С. 76-81.

17. Klimm D., Nippelt B., Paufler P., and Haasen H. Ultrasound treatment of GaP and GaAs. Phys.st.sol (a) - 1993 - T.138. - C.517-523.

18. Гонтарук О.М., Мачулин В.Ф., Оліх Я.М., Корбутяк Д.В., Корбут Е.В., Тартачник В.П.. Деградационно-релаксационные явления в светоизлучающих p-n структурах на основе фосфида галия, стимулированные УЗ. Письма в ЖТФ, 1998, - Т. 24, №15, C.64-68.

19. Островский И. В., Коротченков О. А. Акустопроводимость кристаллов ZnS // ФТТ. Т. 2. - В. 1. - 1983. - С. 259-261. Влияние ядерной радиации и ультразвука на фотопроводимость кремния // ЖТФ. - Т. 56. - 1986. - С. 2283.

20. Баранский П.И., Олих Я.М., Суханов К.С. Акустопроводимость полупроводниковых кристаллов $\mathrm{Cd}_{\mathrm{x}} \mathrm{Hg}_{1-\mathrm{x}}$ Те // Материалы XIII Всесоюзн. конф. по акустоэлектронике и квантовой акустике: Тез. - Ч. 1. - Черновцы. - 1986. - С. 61-62.

21. Островский И.В., Рожко А.Х. Акустоперегруппировка дефектов в кристаллах // ФТТ. - 1984. - Т. 24, №12. - С. 3728-3720.

22. Громашевский В.Л., Дякин В.В., Сальков Е.А., Скляров С.М., Хилимова Н.С. Акустохимические реакции в сульфиде кадмия // УФЖ. - 1984. - Т. 29, №4. - С. 550554.

23. Бритун В.Ф., Горидько Н.Я., Корчная В.А., Семенова Г.Н., Скороход.М.Я., Ехорик Ю.А., Хазан Л.С., Шейкман М.К. Стимулированные УЗ структурные изменения в напряженных гетеросистемах. ФТТ. - 1991. - Т.33, №8. - 2340-2344.

24. Ермолович И.Б., Миленин В.В.. Конакова Р.В., Применко Л.Н., Прокопенко И.В., Громашевский В.Л. Влияние ультразвуковой обработки на деформационные эффекты и структуру локальных центров в подложке и приконтактных областях структур M/nn+-GaAs (M=Pt, Cr, W) // ФТП. - 1997. — T. 31, №4. - С. 503-507.

25. Венгер Е.Ф., Ермолович И.Б., Миленин В.В., Конакова Р.В., Чайка Г.Е. Влияние внешних радиационных, СВЧ- и механических возбуждений на образование дефектов в неметаллических кристаллах // Вопросы атомной науки и техники. — 1999. - В. 3 №75. - С. 60-72.

26. Островский И.В., Коротченков О.А. Влияние ядерной радиации и ультразвука на фотопроводимость кремния // ЖТФ. — 1986. — Т. 56, №11 - - С. 2283-2284.

27. Островский И.В., Коротченков О.А., Лысых В.А. Отжиг точечных дефектов ультразвуком в твердых телах // ФТТ. - 1987. — Т. 20, №7. — С. 2153-2156.

28. Olikh Ya.M., Tartachnik V.P., Tichyna I.I. Vernidub R.M. Termoacoustic annealing of radiationinduced defects in indium-phosphide crystals // The proceeding of $5^{\text {th }}$ conference "Acoustoelectronics' 91". — Varna (Bulgaria). — 1991. — P. 95-96.

29. Олих Я.М., Карась М.И. О влиянии ультразвука на отжиг радиационных дефектов в нейтронно-легированном германии // ФТП. - 1996. - Т. 30, №8. -С. 1455-1459.

30. Баранский П.И., Винецкий Р.М., Городничий О.П., Горбатюк И.Н., Олих Я.М., 
Раренко И.М. Влияние ультразвука на гальваномагнитные эффекты в n-(Cd, $\mathrm{Hg}) \mathrm{Te} / /$ ФТП. — 1986. — Т. 20, №6. - С. 1104-1106.

31. Любченко А.В., Мысливец К.А., Олих Я.М. Рекомбинация носителей через акцепторные уровни собственных дефектов в кристаллах $\mathrm{n}-\mathrm{Cd}_{\mathrm{x}} \mathrm{Hg}_{1-\mathrm{x}} \mathrm{Te}$, подвергнутых ультразвуковой обработке // ФТП. - 1990. — Т. 24, №1 - — С. 171-174.

32. Караченцева Л.А., Любченко А.В., Мысливец К.А., Олих Я.М. Особенности акустического воздействия на кристаллы $\mathrm{Cd}_{\mathrm{x}} \mathrm{Hg}_{1-\mathrm{x}}$ Те с разным содержанием собственных акцепторов // УФЖ. - 1990. — Т. 35, №3. — С. 468-472.

33. Баранский П.И., Беляев А.Е., Комиренко С.М., Шевченко Н.В. Механизм изменения подвижности носителей заряда при ультразвуковой обработке полупроводниковых твердых растворов // ФТТ. - 1990. - Т. 32, -№7. - С. 2159-2161.

34. Гарягдыев Г., Городецкий И.Я., Джумаев Б.Р., Корсунская Н.Е., Раренко И.М., Шейкман М.К. Механизмы изменения электрических и фотоэлектрических свойств под действием УЗ. ФТП. - 1991. - Т.25, №3. - С.409-412.

35. Бабенцов Б.Н., Горбань С.И., Городецкий И.Я., Корсунская Н.Е., Раренко И.М., Шейкман М.К. Влияние УЗ обработки на экситонную и примесную люминесценцию СdTе . ФТП. - 1991. - Т.25, №7. - С.1243-1245.

36. Власенко А.И., Олих Я.М., Савкина Р.К. Акустостимулированная активация связанных дефектов в твердых растворах $\mathrm{Cd}_{\mathrm{x}} \mathrm{Hg}_{\text {1-х }}$ Те // ФТП.-Т. 33.-В. 4.-1999.-С. 410-414.

37. Власенко А.И., Олих Я.М., Савкина Р.К. Подвижность носителей заряда в кристаллах $\mathrm{n}-\mathrm{Cd}_{\mathrm{x}} \mathrm{Hg}_{1-\mathrm{x}}$ Те в условиях динамического ультразвукового нагружения // ФТП. - 2000. — T. 34, №6. - С. 670-675.

38. Бабич В. М., Оліх Я. М., Тимочко М. Д. Вплив УЗ на транспортні явища в бездислокаційних кристалах $p$-Ge. Матеріали конфер “Актуальні проблеми фізики напівпровідників". Дрогобич, 24-27 червня 2003p., с.7.

39. Ostapenko S., Jastrzebski L., Sopori B. Change of minority carrier diffusion length in polycrystalline silicon by ultrasound treatment // Semicond. Sci. Technol. — 1995. — Vol. 10, N11. — P. 1494-1500.

40. Ostapenko S., Bell R. Ultrasound stimulated dissociation of Fe-B pair in silicon // J. Appl. Phys. — 1995. — Vol. 77, N10. — P. 5458-5460.

41. Олих О.Я., Островский И.В. Увеличение длины диффузии электронов в кристаллах ркремния под действием ультразвука // ФТТ. — 2002. — Т. 44, №7. — С. 1198-1201.

42. Korotchenkov O.A., Grimmeiss H.G. Long-wavelength acoustic-mode-enhanced electron emission from Se and Te donors in silicon // Phys. Rev. B. - 1995. - Vol. 52, N20. — P. 1459814606.

43. Korotchenkov O.A., Goto T. Study on bound exciton dynamics in CdS crystals at acoustic driving // Physica B. - 1998. - Vol. 253, N3-4. - P.203-214.

44. Парчинский П.Б, Власов С.И., Лигай Л.Г., Щукина О.Ю. Влияние ультразвукового воздействия на генерационные характеристики границы раздела кремний-диоксид кремния // Письма в ЖТФ. - 2003. - Т. 29, №9. - С. 83-88.

45. Wosinski T., Makosa A., Witczak Z. Transformation of native defects in bulk GaAs under ultrasonic vibration // Semicond. Sci. Technol. — 1994. — Vol. 9, N11. — P. 2047-2052.

46. Buyanova I.A., Ostapenko S.S., Shinkman M.K., Murrikov M. Ultrasound regeneration of EL2 centers in GaAs // Semicond. Sci. Technol. — 1994. — Vol. 9, N2. — P.158-162.

47. Belyaev A.E., von Bardeleben H.J., Fille M.F., Oborina E.I., Ryabchenko Ya.S., Savchuk A.U., Sheinkman M.K. The ultrasonic-induced quenching of the persistent photoconductivity related to DX centers in AlGaAs // Mater. Sci. Forum. — 1994. — Vol. 143-147, pt. 2. — P. 1057-1061. 
48. Заверюхин Б.Н., Заверюхина Н.Н., Турсункулов О.М. Изменение коэффициента отражения излучения от поверхности полупроводников в спектральном диапазоне $\lambda=0.2 \div 20 \mu \mathrm{m}$ под воздействием ультразвуковых волн // Письма в ЖТФ. - 2002. - Т. 28, №18. - С. 1-12.

49. Островский И.В., Стебленко Л.П., Надточий А.Б. Образование поверхностного упрочненного слоя в бездислокационном кремнии при ультразвуковой обработке // ФТП, 2000, 34, №3, с.257-260.

50. Парчинский П.Б, Власов С.И., Муминов Р.А., Исмаилов Х.Х., Тургунов У.Т. Влияние ультразвука на параметры структур металл-диэлектрик-полупроводник // Письма в ЖТФ. - 2000. — Т. 26, №10. - C. 40-45.

51. Krüger D., Romanyuk B., Melnik V., Olikh Ja., and Kurps R. Influence of in-situ ultrasound treatment during ion implantation on amorphization and junction formation in silicon. // J.Vac.Sci.Technol. — 2002. - B20, N 4. - P. 1448-1452.

52. Krevchik V.D., Muminov R.A., Yafasov A.Ya. Influence of ultrasound on ionic diffusion process in semiconductors // Phys. Stat. Sol. (a). — 1981. — Vol. 63, N2. - P. K159-K162.

53. Аракелян В.С., Авакян А.А., Капанакцян Л.К. Перераспределение точечных дефектов в $\mathrm{NaCl}$ в поле стоячей ультразвуковой волны // ФТТ. - 1985. — Т. 27, №8. - С. 25362537

54. Бакай А.С., Лозинский И.П. Влияние звука на диффузию атомов примеси внедрения в твердом теле // ФТТ. — 1986. — Т. 28. — №8. — С. 2455-2457.

55. Pavlovich V.N. Enhanced diffusion of impurities and defect in crystal in conditions of ultrasonic and radiative excitation of crystal lattice // Phys. Stat. Sol. (b). — 1993. — Vol. 180, N1 . — P.97105.

56. Олих Я.М., Шавлюк Ю.Н. Акустостимулированное подавление шума $1 / \mathrm{f}$ в субблочных кристаллах $\mathrm{Cd}_{0.2} \mathrm{Hg}_{0.8}$ Te // ФТТ. — 1996. — Т. 38, №11. — С. 3365-3371.

57. Bell R.E., Ostapenko S., Lagowski J. Ultrasound defect engineering of transition metals via metal-acceptor pairs in silicon // Defect and impurity engineered semiconductors and devices. Pittsburgh, PA: Material Research Society, 1995. — P. 647-652.

58. Ostapenko S., Jastrzebski L., Lagowski J., Smeltzer R.K. Enhanced hydrogention in polycrystalline silicon thin films using low-temperature ultrasound treatment // Appl. Phys. Lett. — 1996. _ Vol. 68, N20. - P. 2873-2875. 